\title{
Tawazaun
}

Jurnal Pendidikan Islam

http://ejournal.uika-bogor.ac.id/index.php/TAWAZUN/index

Vol. 13, No. 2, 2020, e-ISSN: 2654-5845, hlm. 103-112, DOI: 10.32832/tawazun.v13i2.3150

\section{Analisis Pemahaman Guru Terhadap Standar Pendidik Dan Tenaga Kependidikan (PTK) Di Tingkat SMP/MTS}

\author{
Eva Karlina Dwi Astuti*, Chaerul Rochman, Ida Farida, Aan Hasanah \\ Universitas Islam Negeri Sunan Gunung Djati Bandung, Indonesia \\ *evakarlina97@gmail.com
}

\begin{abstract}
Teachers' understanding of aspects related to the standards of educators and education personnel is very important to realize quality education. For this reason, through this research, an analysis of the standards of educators and education staff has been carried out in order to achieve the success of an education. This study aims to interpret or illustrate the data accompanied by the achievement of an understanding of the standard of educators and education staff on PAl Teachers and Non PAl Teachers. This research method is quantitative descriptive. The instrument for collecting data uses questionnaires and interviews. Based on the analysis of data on the understanding of PAI Teachers and Non PAI Teachers that there are indicators whose percentage qualification scores are lacking, namely the 2nd and 17th indicators. The comparison of the percentage of PAI and Non-PAl teachers' understanding of the standards of educators and education personnel is $78.7 \%$ and $78.4 \%$. The results of the triangulation of respondents there are three indicators: the 2nd indicator from PAl teachers and the 16th indicators and the 17th indicators from Non-PAl teachers, so there is a need for more attention and improvement by schools to the difficulties faced in the standards of educators and educational.
\end{abstract}

Keywords: understanding; teacher; standards of educators; educational staff

Abstrak

Pemahaman guru terhadap aspek-aspek yang terkait dengan standar pendidik dan tenaga pendidikan sangat penting untuk merealisasikan penyelenggaraan pendidikan yang berkualitas. Untuk itu melalui penelitian ini telah dilakukan analisis terhadap pemahaman standar pendidik dan tenaga kependidikan guna mencapai keberhasilan dari suatu pendidikan. Penelitian ini bertujuan untuk melakukan penafsiran atau menggambarkan data disertai dengan ketercapaian pemahaman standar pendidik dan tenaga kependidikan pada Guru PAI dan Guru Non PAI. Metode penelitian ini adalah kuantitatif deskriptif. Instrumen untuk mengumpulkan data menggunakan angket dan wawancara. Berdasarkan hasil analisis data pemahaman Guru PAI dan Guru Non PAl bahwa terdapat indikator yang nilai kualifikasi presentasinya kurang yaitu pada indikator ke-2 dan indikator presentasinya ke-17. Perbandingan persentase pemahaman Guru PAI dan Non PAI terhadap standar pendidik dan tenaga kependidikan ialah 78,7 \% dan 78, $4 \%$. Hasil triangulasi responden ada tiga indikator yaitu: indikator ke-2 dari Guru PAI dan indikator ke-16 serta indikator ke-17 dari Guru Non PAI, sehingga perlu adanya perhatian lebih dan perbaikan oleh sekolah terhadap kesulitan yang dihadapi pada standar PTK.

Kata kunci: pemahaman; guru; standar pendidik; tenaga kependidikan

Article Information: Received July 1, 2020, Accepted November 24, 2020, Published Desember 29, 2020 Published by: Program Studi Magister Pendidikan Agama Islam Universitas Ibn Khaldun Bogor How to cite: Astuti, E. K. D., Rochman, C., Farida, I., \& Hasanah, A. (2020). Analisis Pemahaman Guru Terhadap Standar Pendidik Dan Tenaga Kependidikan (PTK) Di Tingkat SMP/MTS. Tawazun: Jurnal Pendidikan Islam, 13(2). doi: 10.32832/tawazun.v13i2.3150 


\section{Pendahuluan}

Tercapainya tujuan pendidikan bergantung pada para pendidik dan tenaga kependidikan, terutama pada seorang pendidik (Nurmansyah, n.d.). Pendidik merupakan tokoh utama yang menduduki peran yang sangat penting bagi keberlangsungan proses pembelajaran di suatu lembaga pendidikan (Rahmah, 2017). Selain itu, keprofesionalitasan seorang pendidik sangat dibutuhkan oleh setiap lembaga pendidikan karena dapat menciptakan lulusan yang berkualitas (Saputra, Jairi, \& Rohaetin, 2019). Sehingga seorang pendidik dan tenaga kependidikan dituntut untuk senantiasa meningkatkan standar kompetensi yang dimilikinya agar mencapai tujuan pendidikan secara optimal. Sayangnya, saat ini pendidikan masih banyak yang mengalami berbagai permasalahan terutama yang dirasakan oleh guru.

Permasalahan-permasalahan yang terjadi yang sesuai dengan keadaan guru, di antaranya yaitu: (1) perbedaan kemampuan antar guru dalam memonitoring kegiatan belajar mengajar, juga dalam penguasaan materi pelajaran, (2) keakuratan alat ukur yang belum memadai untuk mengetahui kompetensi yang dimiliki oleh seorang guru, (3) kebutuhan guru belum terpenuhi dari proses pembinaan dan pelatihan (4) kesejahteraan belum dirasakan oleh guru. Jika permasalahan tersebut tidak cepat teratasi, maka hal tersebut akan membuat kualitas pendidikan yang rendah (Setiawan, Rochman, \& Arifin, 2019). Oleh karena itu, perlu adanya kajian khusus mengenai analisis pemahaman guru terhadap standar pendidik dan tenaga kependidikan di sekolah/madrasah agar lebih diperhatikan dan mengadakan perbaikan serta mencari solusi untuk memecahkan masalah.

Pemahaman dapat diartikan suatu proses atau cara yang dilakukan untuk memahami sesuatu secara benar (Em Zul \& Senja, 2008: 607-608). Pemahaman guru mengenai standar pendidik dan tenaga kependidikan dilakukan untuk mengetahui sejauh mana tingkat pengetahuannya tentang standar tersebut agar tujuan pendidikan dapat tercapai sesuai dengan harapan. Pemahaman yang baik dapat dipengaruhi oleh beberapa faktor, di antaranya yaitu: kualifikasi akademik, tingkat pendidikan, tugas dan beban waktu mengajar, keikutsertaan dalam program pelatihan, penguasaan metode dan media pembelajaran, intensitas membaca, dan kinerja guru (Ayuni, 2015). Faktor-faktor tersebut dapat memberikan pengaruh yang sangat signifikan pada pemahaman guru terhadap standar pendidik dan tenaga kependidikan.

Dalam penelitian ini, guru diharapkan dapat menyelenggarakan pendidikan secara baik dengan meningkatkan pemahamannya terhadap standar pendidik dan tenaga kependidikan. Pemahaman standar ini dipilih karena penelitian terdahulu menunjukkan bahwa keberhasilan suatu pendidikan tidak jauh dari peran seorang pendidik yang menjadi salah satu kunci atas keberhasilan dalam dunia pendidikan (Nurmansyah, n.d.). Hal ini berarti kompetensi guru sangat dibutuhkan untuk memaksimalkan perannya dalam pendidikan. Penelitian lain memaparkan bahwa secara keseluruhan pada standar pendidik dan tenaga kependidikan memperoleh persentase sebesar 86,3\% sehingga perlu adanya upaya dalam mengoptimalkan permasalahan pada setiap indikator yang kurang di dalamnya. Beberapa upaya yang dapat dilakukan di antaranya lebih sering mendaftarkan guru-guru dan konselor BK kepelatihan yang sesuai keahliannya, bekerja sama bersama murid agar perpustakaan dapat lebih terintegrasi dengan baik (Setiawan et al., 2019). Upaya tersebut diperoleh berdasarkan hasil penelitian pada analisis ketercapaian standar pendidik dan tenaga kependidikan.

Pemerintah Indonesia juga sangat serius dalam menanggapi permasalahan tersebut dibuktikan dengan keseriusannya dalam penetapan peraturan yang berkaitan dengan standar pendidikan. Penetapan standar tersebut didasarkan pada PP nomor 32 tahun 2013 berkenaan dengan perubahan peraturan pemerintah nomor 19 tahun 2005 (pasal 1 ayat 1 dan pasal 2 ayat 1) terkait dengan delapan Standar Nasional Pendidikan (SNP) yang kemudian dijadikan tolok ukur dalam pengembangan kurikulum dibidang pendidikan untuk mencapai tujuan pendidikan secara nasional (Setiawan et al., 2019). Standar nasional pendidikan (SNP) ini 
merupakan kriteria minimum yang terdiri dari delapan standar yang harus dimiliki oleh sistem pendidikan yang ada di seluruh wilayah Indonesia (Karenina, Anjani, Amiela, \& Sajidan, 2015). Delapan Standar Pendidikan Nasional (SNP) tersebut berimplikasi pada upaya yang dilakukan sekolah/madrasah untuk memperbaiki kualitas pengelolaan dalam sistem pendidikan. Terlebih dalam penelitian ini terkait standar pendidik dan tenaga kependidikan.

Analisis pemahaman guru terhadap standar pendidik dan tenaga kependidikan dapat memberikan informasi terkait keberhasilan pendidikan. Oleh karena itu, peneliti tergugah untuk melakukan sebuah penelitian tentang analisis pemahaman standar pendidik dan tenaga kependidikan pada lima (5) Guru PAI dan lima (5) Guru Non PAI dari beberapa sekolah yang ada di Jawa Barat. Peneliti juga berusaha menemukan solusi yang dapat dijadikan alternatif untuk memecahkan permasalahan seputar standar tersebut agar memperoleh nilai standar yang maksimal.

\section{Metode Penelitian}

Metode penelitian ini dengan menggunakan penelitian kuantitatif deskriptif yang berarti mendeskripsikan data disertai dengan analisis atau gambaran pemahaman guru terhadap standar pendidik dan tenaga kependidikan. Data dikumpulkan dengan menggunakan angket melalui Google form dan wawancara. Data Primer dikumpulkan dengan metode angket menggunakan instrumen penilaian berupa pernyataan tentang standar PTK. Sedangkan untuk data sekunder (penunjang) peneliti menggunakan metode wawancara yang dilakukan kepada guru PAI dan Non PAI yang memperoleh skor terendah.

Populasi dalam penelitian ini adalah guru-guru yang mengajar di Sekolah Menengah Pertama (SMP) dan Madrasah Tsanawiyah (MTs). Jumlah sampel yang diambil sebanyak 10 (sepuluh) responden bidang ahli pendidik dan tenaga kependidikan dari berbagai sekolah/madrasah yang ada di Jawa Barat. Responden dari Guru PAI sebanyak 5 (lima) orang dan Guru Non PAI sebanyak 5 (lima) orang. Mereka berjenis kelamin laki-laki 2 (dua) orang dan perempuan 8 (delapan) orang. Instrumen data yang digunakan ialah pedoman angket untuk mendapatkan beberapa informasi pemahaman Guru terhadap standar pendidik dan tenaga kependidikan yang terdiri dari 19 (sembilan belas) indikator, dan wawancara untuk melakukan perbandingan berdasarkan hasil analisis angket dengan hasil wawancara.

Cakupan 19 (sembilan belas) indikator pada standar pendidik dan tenaga kependidikan yaitu: pendidik mempunyai kualifikasi akademik yang sesuai, pendidik harus bersertifikat, pengajar mapel berlatar belakang yang sesuai, pengajar mempunyai kemampuan pedagogik, pengajar mempunyai kemampuan profesional, pengajar mempunyai kemampuan kepribadian, pengajar mempunyai kemampuan sosial, konselor BK mempunyai kemampuan keprofesionalan, perbandingan antara konselor BK dan jumlah seluruh siswa sesuai dengan kapasitas, kepsek/kamad telah memenuhi syarat, kepsek/kamad mempunyai kemampuan manajerial, kepsek/kamad berkemampuan wirausaha, kepsek/kamad berkemampuan supervisi akademik, kepsek/kamad mempunyai ketua staff administrasi sesuai ketentuan, sekolah/madrasah mempunyai staff administrasi dengan kualifikasi pendidikan yang sesuai, ketua perpustakaan telah memenuhi persyaratan, staff perpustakaan mempunyai kualifikasi akademik min. SMA/setingkat dan bersertifikat, sekolah/madrasah mempunyai laboran yang ahli, serta sekolah/madrasah mempunyai petugas layanan khusus.

Adapun tahapan-tahapan dalam penelitian sebagai berikut: menyusun instrumen angket berupa pernyataan dengan pilihan jawaban, mengumpulkan data, merekap data dan memberi skor, menginterpretasikan data, mengitung prosentase, rata-rata, tertinggi, terendah, serta mentriangulasi data. Ketentuan ketercapaian hasil analisis data yang diperoleh dari tiap indikator jawaban responden sebagai berikut: 
Tabel I. Skor Per indikator Jawaban Responden

\begin{tabular}{lll}
\hline No. & Indikator yang dicapai & Skor \\
\hline I & Tidak Ada/Sangat Tidak Setuju & $\mathrm{I}$ \\
\hline $\mathbf{2}$ & Sebagian Kecil/Tidak Setuju & 2 \\
\hline 3 & Sebagian Besar/Setuju & 3 \\
\hline $\mathbf{4}$ & Seluruhnya/Sangat Setuju & 4 \\
\hline \multicolumn{2}{c}{ Sumber: Evadir Akreditasi Tahun 20I7 }
\end{tabular}

Berdasarkan ketentuan pada tabel di atas, maka skor maksimal yang diperoleh sebesar 76 poin. Adapun rumus hitungan persentase tiap nilai adalah prosentasi ketercapaian $=$ $\frac{\text { Perolehan Skor }}{\text { Skor Maksimum }} \times 100 \%$. Penentuan kualifikasi persentase ketercapaian indikator dengan menggunakan tabel berikut:

Tabel 2. Skor Per indikator Jawaban Responden

\begin{tabular}{lll}
\hline No. & Persentase Ketercapaian & Kualifikasi \\
\hline $\mathrm{I}$ & $<6 \mathrm{I} \%$ & Sangat Kurang \\
\hline 2 & $6 \mathrm{I}-70 \%$ & Kurang \\
\hline 3 & $7 \mathrm{I}-80 \%$ & Cukup \\
\hline 4 & $8 \mathrm{I}-90 \%$ & Baik \\
\hline 5 & $9 \mathrm{I}-100 \%$ & Unggul \\
\hline
\end{tabular}

Sumber: Evadir Akreditasi Tahun 2017

Hasil analisis data yang diperoleh kemudian dilakukan dengan triangulasi data untuk menguji keabsahan data. Pada hakikatnya triangulasi ialah pendekatan multi metode yang dilakukan oleh peneliti ketika ia melakukan pengumpulan dan menganalisis data (Rahardjo, 2019). Triangulasi tersebut dilakukan terhadap data skor responden dengan ketercapaian indikator yang paling rendah dengan melakukan wawancara terkait permasalahan yang dihadapi dan alternatif pemecahannya.

\section{Hasil dan Pembahasan}

\section{A. Temuan Penelitian}

Berdasarkan hasil survei dari yang dilakukan dengan menggunakan angket dan hasil pengolahan data terkait pemahaman standar Pendidik dan Tenaga Kependidikan (PTK) dari lima (5) guru PAI dan lima (5) guru Non PAI dari beberapa sekolah yang ada di Jawa Barat, maka berikut ini peneliti akan menyajikan informasi terkait dengan profil pemahaman, perbandingan persentase pemahaman dan analisis kesulitan guru berdasarkan pemahamannya terhadap standar Pendidik dan Tenaga Kependidikan.

\section{B. Profil Pemahaman Standar Pendidik dan Tenaga Kependidikan (PTK) Berdasarkan Indikator pada Guru PAI dan Non PAI}

Profil pemahaman standar PTK berdasarkan indikator pada 5 Guru PAI dan 5 Guru Non PAI, dapat disajikan melalui diagram batang, sebagai berikut: 


\section{Profil Pemahaman Standar PTK Berdasarkan Indikator pada Guru} PAl dan Non PAI

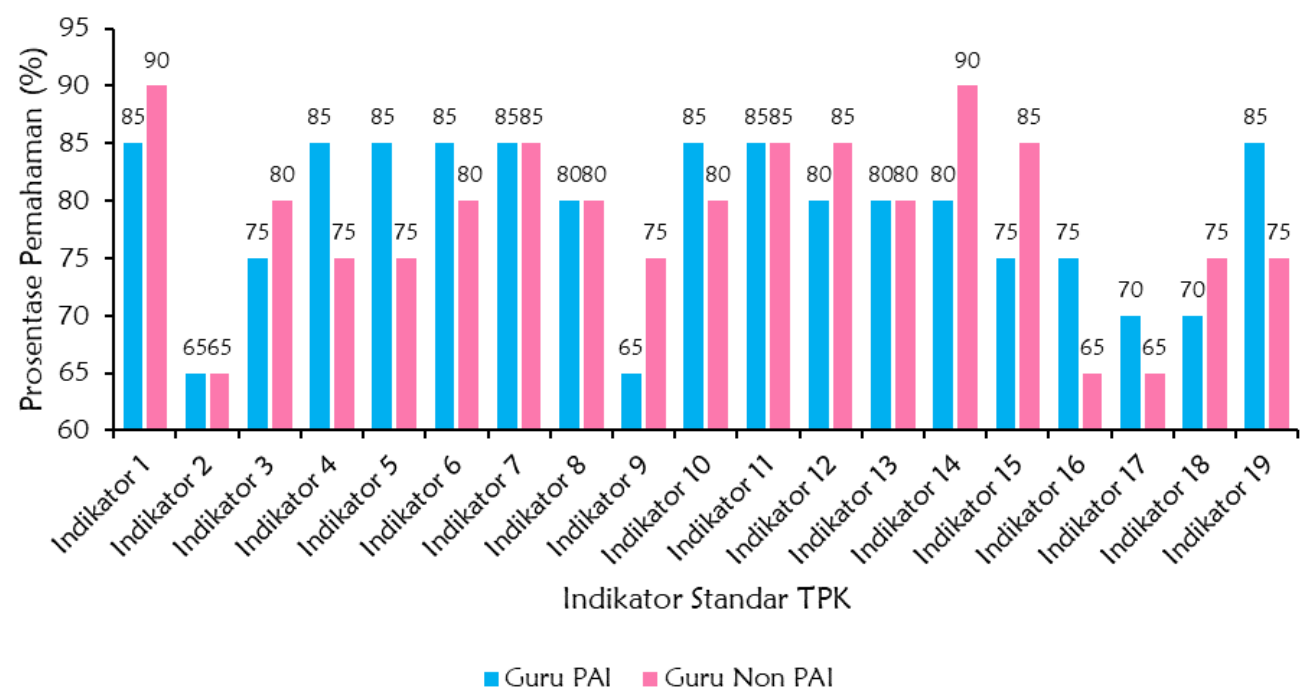

Gambar I. Profil Pemahaman Standar Pendidik dan

Tenaga Kependidikan Guru PAI dan Non PAI

Berdasarkan gambar 1 menunjukkan bahwa profil pemahaman standar pendidik dan tenaga kependidikan (PTK) bagi Guru PAI dan Non PAI berdasarkan 19 indikator bervariasi. Terdapat indikator dari pemahaman guru PAI yang nilai kualifikasi persentasenya kurang yaitu pada indikator ke-2 terkait guru yang telah tersertifikasi dengan menunjukkan besar persentase $65 \%$, indikator ke- 9 terkait rasio guru BK dengan menunjukkan besar persentase $65 \%$, indikator ke-17 terkait staff perpustakaan yang belum tersertifikat dengan menunjukkan besar persentase $70 \%$, dan indikator ke-18 terkait menunjukkan laboran di sekolah/madrasah yang mempunyai kualifikasi akademik sesuai standar tenaga laboratorium dengan menunjukkan besar persentase $70 \%$. Secara keseluruhan ketercapaian standar PTK Guru PAI sebesar 78,7 \%.

Kemudian, terdapat juga indikator dari pemahaman guru Non PAI yang nilai kualifikasi persentasenya kurang yaitu pada indikator ke-2 terkait guru yang telah tersertifikasi dengan menunjukkan besar persentase $65 \%$, indikator ke-16 terkait kepala perpustakaan memenuhi syarat dengan menunjukkan besar persentase $65 \%$, dan indikator ke-17 terkait staff perpustakaan yang belum tersertifikat dengan menunjukkan besar persentase $65 \%$. Secara keseluruhan ketercapaian standar PTK pada Guru Non PAI sebesar 78,4 \%.

Berdasarkan hasil analisis data pemahaman Guru PAI dan Non PAI terhadap standar PTK tersebut dapat ditarik kesimpulan bahwa skor indikator standar yang belum maksimal terdapat pada indikator sebagai berikut:

Pertama, terkait guru yang bersertifikat. Dilihat dari sebuah penelitian yang mengatakan bahwa program sertifikasi ini dapat memperkuat kepemimpinan seorang guru, memperkukuh landasan pengetahuan, dan menambah pengalaman bagi seorang guru di sekolah (Humphrey, Wechsler, \& Hough, 2008). Senada dengan itu pendapat lain juga mengatakan bahwa keefektifan yang dihasilkan akan sama, baik dari seorang guru yang bersertifikat ataupun yang belum bersertifikat dengan catatan ia mendapatkan pelatihan terkait keguruan. Berdasarkan analisis prestasi pada siswa kelas IV dan V terbukti bahwa guru tersertifikasi secara konsisten dapat menciptakan prestasi siswa yang lebih unggul daripada guru yang belum tersertifikasi (Darling-Hammond, Holtzman, Gatlin, \& Heilig, 2011). Pengajar yang memperoleh nilai uji sertifikasi bisa menciptakan perolehan hasil belajar pada 
peserta didik yang meningkat dan bisa meminimalisir pelamar yang belum tersertifikasi sebagai pemenuhan syarat menjadi seorang pendidik (Boyd, Goldhaber, Lankford, \& Wyckoff, 2007). Sehingga adanya program sertifikasi sangat penting untuk menciptakan guru dan siswa yang berkualitas.

Kedua, terkait dengan rasio perbandingan konselor BK dengan jumlah peserta didik. Dilihat dari penelitian yang menyatakan bahwa rasio perbandingan konselor BK dengan jumlah peserta didik itu sesuai peraturannya yaitu 150:1 di setiap sekolah dengan lama kerja sebanyak $24 \mathrm{jam} /$ minggu. Dari hasil analisanya menyatakan bahwa hal yang demikian itu tidak cukup dalam pemenuhan kebutuhan pada pelayanan BK bagi peserta didik secara pribadi dan komprehensif. Pelayanan konseling yang diberikan pada setiap kelas tidak akan menjamin terpenuhinya kebutuhan pelayanan BK (Zamroni, Edris, \& Rahardjo, 2015). Sehingga peserta didik mendapatkan bimbingan konseling secara menyeluruh.

Ketiga, terkait dengan staff perpustakaan yang telah tersertifikasi. Berdasarkan penelitian dengan menyebarkan 3000 angket dihasilkan bahwa peran pustakawan di sekolah dalam menyediakan berbagai informasi untuk membantu belajar peserta didik di Turki maka diperlukan sebuah bimbingan penggunan supaya proses bimbingan akan lebih maksimal dan juga menciptakan pelayanan yang lebih optimal.(Önal, 2005). Kemudian, diperkuat dengan argumen lain yang menyatakan bahwa adanya pelatihan terkait dengan kepustakawanan akan meningkatkan wawasan bagi staff perpustakaan, hal ini terlihat dari hasil uji awal dan uji akhir yang dilakukan dapat menghasilkan perbedaan ketercapaian hasil pengujian. Hasil pelatihan tersebut terbukti sangat efektif dalam mentransferkan wawasan ilmu, kepribadian, dan keterampilan kepada staff perpus dalam menjalankan tugasnya sebagai pengelola perpustakaan (Dewi, Laksmi, \& Suhardini, 2014).

Keempat, terkait kepala perpustakaan memenuhi syarat. Dilihat dari penelitian terdahulu bahwa kualifikasi akademik yang dimiliki oleh kepala perpustakaan setidaknya paling rendah itu S1 dibidang ilmu perpustakaan atau bisa dibidang ilmu yang lain tetapi ditambah keikutsertaannya dalam diklat perpustakaan (Saputro \& Amir, 2018). Kelima, terkait laboran di sekolah/madrasah yang mempunyai kualifikasi akademik sesuai standar tenaga laboratorium. Berdasarkan penelitian terdahulu menyatakan bahwa seorang laboran ditempatkan sesuai kemampuannya pada struktur organisasi, ia harus terampil dalam menjaga dan memelihara alat labor, kehati-hatian saat bekerja serta menimbulkan kenyamanan dan keamanan bagi para praktikan (Budiada \& Lasia, 2014). Pendapat ini diperkuat dalam penelitian lain yang mengatakan bahwa suatu laboran dapat dikatakan baik ketika telah memenuhi sebagaimana yang termuat dalam permendiknas No. 26 tahun 2008 tentang Standar Tenaga Laboratorium Sekolah/Madrasah telah menetapkan ada 4 kompetensi utama yang wajib terpenuhi oleh seorang laboran yaitu: kepribadian, sosial, administratif, dan profesional (Susilo \& Amirullah, 2018). Emda dalam penelitiannya juga mengatakan bahwa laboratorium sangat membantu penguasaan peserta didik terhadap konsep maupun keterampilan kegiatan ilmiah (Emda, 2017).

Berdasarkan informasi di atas, maka masalah utama yang dihadapi oleh guru PAI maupun Guru Non PAI adalah kelemahan pada indikator ke-2 terkait guru yang tersertifikasi. Kelemahan mungkin diakibatkan oleh kurangnya perhatian sekolah dalam mengikutsertakan guru-guru yang belum tersertifikat sehingga pelaksanaan dan hasil pembelajaran yang dicapai kurang efektif. Selain itu, kelemahan lain yang dialami Guru PAI dan Guru Non PAI adalah kelemahan pada indikator ke-17 terkait staff perpustakaan yang belum bersertifikat. Kelemahan ini mungkin diakibatkan oleh keterbatasan pengetahuan yang dimiliki oleh staff perpustakaan dan juga sekolah yang kurang memerhatikannya dalam keikutsertaan dalam pelatihan pengelolaan perpustakaan sehingga sistem pengelolaan dan pelayanan saat bertugas kurang efektif dan kurang terprogram dengan baik. 


\section{Perbandingan Persentase Pemahaman Standar Pendidik dan Tenaga Kependidikan}

Perbandingan presentasi pemahaman standar pendidik dan tenaga kependidikan pada Guru PAI dan Non PAI ditunjukkan pada gambar 2 berikut:

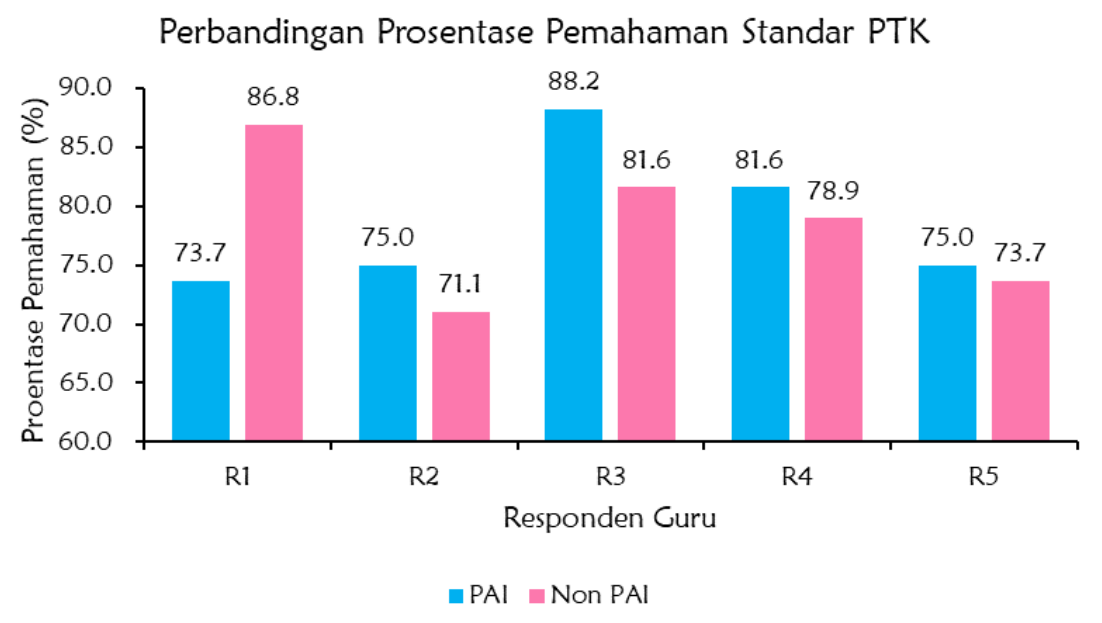

Sumber: Hasil Angket Penelitian

Gambar 2. Perbandingan persentase Pemahaman Standar PTK

Gambar 2 menunjukkan perbandingan pemahaman standar pendidik dan tenaga kependidikan dari Guru PAI dan Non PAI. Terdapat Guru PAI yang presentasi jawabannya paling rendah di antara Guru PAI yang lain yaitu pada responden 1 dengan persentase jawaban $73,7 \%$, sedangkan pada guru Non PAI yang presentasi jawabannya paling rendah di antara Guru Non PAI yang lain yaitu pada responden 2 dengan persentase jawaban 71,1 $\%$.

Kemudian, perbandingan rata-rata persentase standar pendidik dan tenaga kependidikan antara Guru PAI dan Non PAI ditunjukkan pada gambar berikut:

\section{Perbandingan Rata-rata Pemahaman Standar PTK}

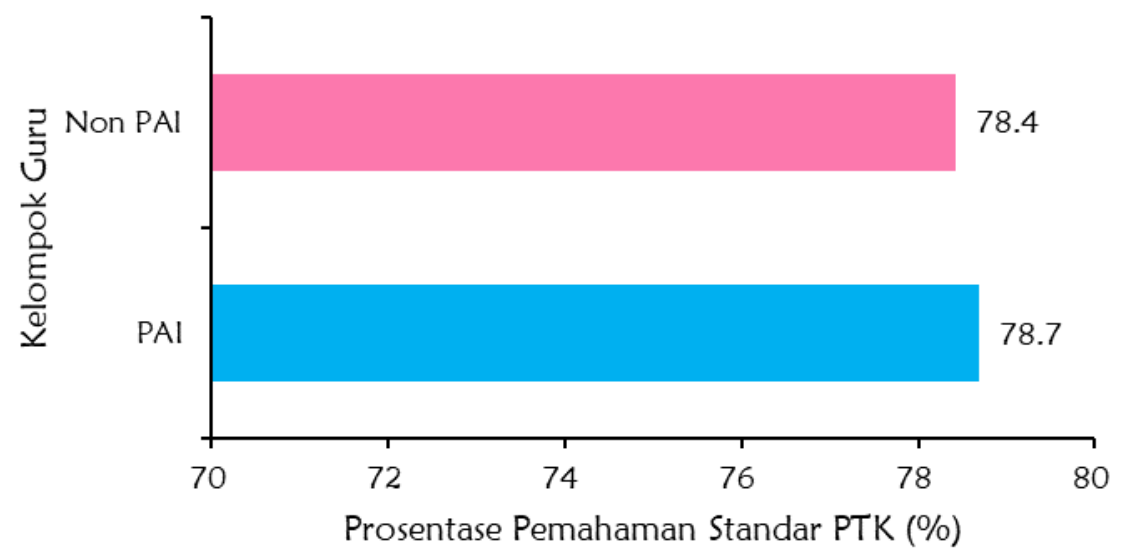

Sumber: Hasil Angket Penelitian

Gambar 3. Perbandingan Rata-rata persentase Pemahaman Standar PTK

Gambar 3 menunjukkan bahwa perbandingan rata-rata persentase pemahaman standar PTK antara Guru PAI yakni 78,7 \% dan Guru Non PAI yakni 78,4, sehingga dapat kita 
ketahui bahwa nilai persentase pemahaman standar Pendidik dan Tenaga Kependidikan (PTK) pada Guru PAI dan Non PAI tidak jauh berbeda.

Berdasarkan informasi yang telah dipapar terdahulu, maka dapat diketahui bahwa pencapaian pemahaman indikator PTK pada Guru PAI cenderung lebih unggul dibandingkan dengan Guru Non PAI. Pemahaman yang kurang bagi Guru Non PAI terletak pada responden 2 sebesar 71,1\%. Padahal pemahaman guru terhadap standar PTK ini akan berpengaruh terhadap kualitas kelulusan peserta didik, karena kualitas seorang pendidik dihubungkan dengan kompetensi yang ia miliki sebagai acuan dalam menentukan keprofesionalan seorang pendidik (Rahmah, 2017). Jika ingin menciptakan lulusan yang berkualitas maka seorang pendidik juga harus berkualitas.

\section{Analisis Kesulitan Guru Berdasarkan Pemahamannya terhadap Standar Pendidik dan Tenaga Kependidikan}

Berdasarkan persentase dari perolehan dan analisis data di atas, peneliti melakukan triangulasi untuk mendalami jawaban dari beberapa orang responden. Responden terdiri dari satu orang guru PAI dan satu orang guru Non PAI. Adapun terkait kesulitan terhadap indikator ke-2 ditanyakan kepada responden 1 untuk guru PAI, sedangkan indikator ke-16 dan ke-17 ditanyakan kepada responden 2 untuk guru Non PAI. Pertanyaan yang diungkapkan adalah 1) apa masalah yang Bapak/Ibu alami? 2) bagaimana menurut Bapak/Ibu upaya yang dapat dilakukan untuk memecahkan masalah tersebut?

Hasil triangulasi data berdasarkan wawancara terkait kesulitan dan alternatif pemecahan (solusi) dari pemahaman Guru PAI dan Non PAI terhadap indikator standar PTK, sebagai berikut: pertama, pada indikator ke-2 ini dirasakan oleh seorang Guru PAI (Responden 1) terkait dengan guru yang belum tersertifikasi disebabkan oleh kurangnya perhatian dari sekolah dalam mengikutsertakan guru tersebut pada program sertifikasi. Di samping itu persyaratan untuk mengikuti program sertifikasi juga dipersulit. Menurut responden 1 solusi yang dapat dilakukan adalah diharapkan bahwa pihak sekolah dapat lebih memerhatikan dan mengikutsertakan guru-guru yang belum bersertifikat pada program sertifikasi yang dilaksanakan oleh pemerintah.

Kedua, pada indikator ke-16 ini dirasakan oleh seorang Guru Non PAI (Responden 2) terkait kepala perpustakaan yang belum memenuhi syarat disebabkan perhatian sekolah yang kurang terhadap keikutsertaan kepala perpus dalam program sertifikasi. Adapun solusi yang dapat dilakukan adalah diharapkan agar pihak sekolah mengirimkan/ mengajukan kepala perpustakaan untuk mengikuti program diklat tentang sistem pengelolaan perpustakaan berdasaran yang telah pemerintah tetapkan.

Ketiga, pada indikator ke-16 ini juga dirasakan oleh seorang Guru Non PAI (Responden 2) terkait kualifikasi akademik dan sertifikat staff perpus. Sebenarnya syarat kualifikasi akademik (min. SMA) telah terpenuhi, tetapi beliau masih kebingungan dengan tupoksi yang harus dikerjakan. Di samping itu, ia juga belum memahami sistem tata kelola perpustakaan dengan baik, sehingga kurang terperdaya dan kurang berguna serta kurang menarik minat siswa dalam membaca. Hal ini disebabkan kurangnya keikutsertaan staff perpus dalam program pelatihan keahlian. Menurut responden 2 solusi yang dapat dilakukan adalah perlu adanya perbaikan dan pelatihan dalam sistem tata kelola perpustakaan, sehingga perpustakaan yang dikelolanya dapat terperdaya dan berguna.

Berdasarkan hasil triangulasi tersebut menunjukkan bahwa terdapat beberapa indikator yang kualifikasinya masih rendah. Rata-rata permasalahan yang dihadapi adalah masih terdapat pendidik dan tenaga pendidik yang belum memenuhi syarat sertifikasi sehingga keahliannya belum bisa dipertanggungjawabkan. Padahal adanya pelatihan terkait dengan kepustakawanan akan meningkatkan wawasan dan sangat efektif dalam menjalankan 
tugasnya sebagai pengelola perpustakaan (Dewi et al., 2014). Selain itu, pengajar yang memperoleh nilai uji sertifikasi juga bisa menciptakan peningkatan hasil belajar siswa dan bisa meminimalisir pelamar yang belum tersertifikasi sebagai pemenuhan syarat menjadi seorang pendidik (Boyd et al., 2007). Sehingga solusi yang dapat dijadikan alternatif adalah disarankan bagi mereka agar mendapatkan pelatihan dan mengikuti program sertifikasi sesuai keahlian dibidangnya masing-masing berdasarkan pengajuan dari sekolah/madrasah.

\section{Kesimpulan}

Berdasarkan analisis data dan pembahasan terhadap pemahaman standar pendidik dan tenaga kependidikan pada Guru PAI dan Guru Non PAI bervariasi. Permasalahan yang dialami beberapa guru terletak pada guru dan staff perpustakaan yang masih belum bersertifikat. Hal ini terjadi karena kurangnya perhatian dari pihak sekolah dalam mengajukan guru-guru yang belum tersertifikasi dalam kegiatan pelatihan program sertifikasi yang diagendakan oleh pemerintah melalui lembaga yang ditetapkan. Salah satu upaya yang dapat dilakukan untuk memaksimalkan indikator berdasarkan pemahaman guru PAI dan Non PAI maka beberapa solusi yang dapat dilakukan sekolah ialah dengan lebih memerhatikan dan mengajukan guru-guru dan juga kepala serta tenaga perpustakaan yang belum tersertifikat ke sebuah pelatihan (diklat) yang sesuai dengan bidang keahliannya. Selain itu, perlu adanya kerja sama antar kepala dan tenaga perpustakaan dan juga siswa-siswa agar menciptakan perpustakaan lebih menarik minat baca dan terintegrasi.

\section{Daftar Pustaka}

Ayuni, F. N. (2015). Pemahaman Guru terhadap Pendekatan Saintifik (Scientific Approach) dalam Pembelajaran Geografi. Gea, Jumal Pendidikan Geografi, Vol. 15(No. 2), Hlm 1-7.

Boyd, D., Goldhaber, D., Lankford, H., \& Wyckoff, J. (2007). The effect of certification and preparation on teacher quality. The Future of Children, 45-68.

Budiada, K., \& Lasia, K. (2014). Strategi Pelayanan Prima Di Laboratorium Jurusan Pendidikan Fisika Fmipa Undiksha Singaraja. Seminar Nasional FMIPA UNDIKSHA, 267-274.

Darling-Hammond, L., Holtzman, D. J., Gatlin, S. J., \& Heilig, J. V. (2011). Does teacher preparation matter? Evidence about teacher certification, Teach for America, and teacher effectiveness." education policy analysis archives 13 (2005).Ida Kiantamani Dewi Hermawan. "Evalusi Program SMP Standar Nasional Berdasarkan Standar Nasional Pendidikan. Jurnal Pendidikn Dan Kebudayaan, Vol. 17.

Dewi, Laksmi, \& Suhardini, A. D. (2014). Peran Perpustakaan dan Tenaga Perpustakaan Sekolah/Madrasah dalam Meningkatkan Mutu Pendidikan Di Sekolah/Madrasah. Jakarta: Pemerintah Republik Indonesia.

Em Zul, F., \& Senja, R. A. (2008). Kamus Lengkap Bahasa Indonesia (Ed. Revisi). Semarang: Difa Publishers.

Emda, A. (2017). Laboratorium Sebagai Sarana Pembelajaran Kimia dalam Meningkatkan Pengetahuan dan Ketrampilan Kerja Ilmiah. Lantanida Journal, 5(1), 83-92.

Humphrey, D. C., Wechsler, M. E., \& Hough, H. J. (2008). Characteristics of Effective Alternative Teacher Certification Programs. Teachers College Record 110, 1-63.

Karenina, A., Anjani, D., Amiela, S. D., \& Sajidan, S. (2015). Profil Pemenuhan Standar Nasional Pendidikan Ketuntasan Belajar Berbasis UN dan Proses Pembelajaran di Salah Satu Sekolah Menengah Pertama di Kab. Magetan. In Prosiding SNPS (Seminar NAsional Pendidikan Sains, Vol. 8, 676-684.

Nurmansyah, F. A. (n.d.). Analisis Kritis tentang Kebijakan Standar Pendidik dan Tenaga Pendidik. Dosen Fakultas Tarbiyah Institut Agama Islam Ngawi (LAI) Ngawi.

Önal, H. İ. (2005). New Developments On The Turkish School Library Scene. Journal of Librarianship and Information Science, 141-151. 
Rahardjo, M. (2019). Triangulasi dalam Penelitian Kualitatif. Retrieved from http://www.uinmalang.ac.id/blog/post/read/101001/triangulasi-dalam-penelitian-kualitatif.html

Rahmah, S. (2017). Sertifikasi Sebagai Bentuk Peningkatan Kinerja Pendidik. Jurnal At-Tafkir, Vol. 10(No. 1), 86-101.

Saputra, W. N. A., Jairi, \& Rohaetin, S. (2019). Upaya Kepala Sekolah Dalam Meningkatkan Profesionalisme Guru Di SMA Negeri 1 Tewang Sangalang Garing Kabupaten Katingan. Jurnal Pendidikan Ilmu Pengetabuan Sosial (JPIPS), Vol. 11(No. 2), 270-277.

Saputro, B. I., \& Amir, C. (2018). Kompetensi Pustakawan Perpustakaan Khusus: Studi Kasus Di Perpustakaan Kementerian Pendidikan dan Kebudayaan. Jurnal Dokumentasi Dan Informasi, 39 (2), 207-218.

Setiawan, I., Rochman, C., \& Arifin, B. S. (2019). Analisis Ketercapaian Indikator pada Standar Pendidik dan Tenaga Kependidikan di SMP Muhammadiyah Cipanas. AtTarbawi, Volume. 4, 27-40.

Susilo, \& Amirullah, G. (2018). Pengelolaan dan Pemanfaatan Laboratorium Sekolah bagi Guru Muhammadiyah di Jakarta Timur. Jurnal Solma, Vol. 07, 1227-137.

Zamroni, Edris, \& Rahardjo, S. (2015). Manajemen Bimbingan dan Konseling Berbasis Permendikbud Nomor 111 Tahun 2014. Jurnal Konseling Gusjigang, 1. 